\title{
Women's Participation in the Digital Economy in ASEAN
}

\section{Fitriani Nengsi}

International Relations

Universitas Muhammadiyah Yogyakarta

fitriani.nengsi.2015@fisipol.umy.ac.id

\begin{abstract}
:
Digital economy over the past decade has become popular trend in the world, including in ASEAN. ASEAN, which is the sixth largest economy in the world, enjoys the revenue of the digital economy that reaches 150 billion USD per year. Digital economy's great potential has been widely utilized by society, especially women in ASEAN to improve their standard of living. This paper aims to explain the development of women's participation in digital economy in ASEAN and accompanied by obstacle. The research method is qualitative method with literature study used secondary data. The results of this study indicate large increased in participation of women in digital economy living in urban areas and small increased of women living in rural areas in ASEAN. Understanding of this research may contribute to the improvement and enhancement of women's participation in digital economy, especially for women living in rural areas in ASEAN.
\end{abstract}

Keywords: Women's participation, Digital Economy, ASEAN, rural areas, urban areas

\section{INTRODUCTION}

A seemingly common belief is that the economic condition of women improves with economic development. This is because economic development improves the population's economy, thereby improving women's absolute economic condition. It also increases the education of women and the rest of society which raises awareness about women's inferior position, 
thereby prompting remedial action. Economic development certainly helps to improve women's economic position in Society (Xin, 1996). Economic growth and development as such can contribute to women`s empowerment by driving down substantial inequalities between women and men, enhancing the fight against discrimination (Lechman \& Okonowicz, 2013)

The number of internet user has grown rapidly over the past decade. Online services are most visible and most dynamic part of the digital value chain. In this environment, data and digital technologies are becoming increasingly essential for participation in the global economy. They have boosted the abilities of firms of all sizes and origin to find a niche in global value chains and gain access to new markets. The Internet provides a platform on which entrepreneurs can construct new businesses and commercialize their ideas, lowering entry barriers and freeing up resources for innovative activity. At the macroeconomic level, these trends hold the potential for new sources of productivity and economic growth (Box \& Lopez-Gonzalez, 2017).

ASEAN, as part of the region of the world, also enjoys a great deal from the digital economy. The
ASEAN digital economy currently generates approximately $\$ 150$ billion in revenues per year. ICT investment has evolved phenomenally, which amounted to more than $\$ 100$ billion US in 2014 (Menon, et al., 2016). Currently, there are four industries that driven the rapid growth of digital economy in ASEAN, which are online travel, online media, e-commerce and ride-hailing and ASEAN is currently home to 7 unicorns companies that have reached a valuation above $\$ 1$ billion US which are Grab, Traveloka, G-Jek, SEA Group, Lazada, Razer and Tokopedia (ASEAN UP, 2018).

Women make up for $48,6 \%$ of total population in ASEAN in 2016 (World Bank, 2016). This is a proof that shows women has a profound impact on ASEAN dynamic region. There is increasing interest on how changing technology and world-trade patterns affect women's economy in ASEAN. It has been found that these changes have caused ASEAN women to participate more in the nonagricultural sector. If we consider that females were working in the agricultural sector with no independent income before working in 'low-paid' clerical jobs, we may conclude that the economic position of females improved with the introduction of Information 
Communication and Technology (ICT) (Xin, Loc. Cit.)

ICT, the backbone of the digital economy, is vital tools for the development of women's participation in the digital economy. E-commerce, business management and Internet marketing are all solutions that can generate significant benefits in all areas of business (Economic Commission for Latin America and the Caribbean, 2013). Transforming the position of women in the digital economy within ASEAN as part of this process will bring immense benefits for women themselves, for their families and communities, for national economies and for ASEAN as a whole.

With the fast growth and great benefits from digital economy, people in ASEAN countries has surely taken advantage of it in regards to increase their standard of living. The digital economy has created a lot of opportunities for people to branch in a new way to find their source of living. People are competing to harvest the great potential from digital economy, including men and women. It is, therefore, a great interest to understand about women's participation in the digital economy in ASEAN as the digital economy could be a way to achieve equality between women and men in ASEAN.

\section{THEORETICAL FRAMEWORK}

\section{Concept of Digital Economy}

There is no consensus of what is the acceptable meaning of digital economy. The simple and straightforward meaning is, "an economy based on digital technologies" (Bukht \& Heeks, 2017). However, some experts give the explanation about the broad definition of digital economy.

The concept of digital economy was first introduced by Don Tapscott, in which digital economy is a sociopolitical and economic system that has characteristics as an intelligence space, including information, access to information instruments, information capacity and processing of formation. The first digitally identified digital economy namely ICT infrastructure, e commerce activity and digital distribution of goods and services (Tapscott, 1996).

G20 DETF 2016: G20 Digital Economy Development and Cooperation Initiative; defined digital economy as "....a broad range of economic activities that include 
using digitized information and knowledge as the key factor of production, modern information networks as an important activity space, and the effective use of information and communication technology (ICT) as an important driver of productivity growth and economic structural optimization" (Bukht \& Heeks, Loc. Cit.).

Thus, from all of the definitions above, we can conclude that digital economy is an economy that based on digital technologies and comprises of three main pillars that are Information and Communication Technology (ICT), e-business and ecommerce.
STATISTICS DATA ON WOMEN'S PARTICIPATION

To explain about the development of women's participation in the digital economy in ASEAN, based on the theoretical framework above, the author will use three statistic data which are the percentage of internet user by gender, the percentage of service sector employment by gender and the ICT Development Index in 2013-2017 from 10 member ASEAN countries that will be explain below.

Table 1. The percentage of internet user by gender

\begin{tabular}{|c|c|c|c|c|c|c|c|c|c|c|}
\hline \multirow[b]{4}{*}{ Country } & \multicolumn{10}{|c|}{ Year } \\
\hline & \multicolumn{2}{|c|}{2013} & \multicolumn{2}{|c|}{2014} & \multicolumn{2}{|c|}{2015} & \multicolumn{2}{|c|}{2016} & \multicolumn{2}{|c|}{2017} \\
\hline & \multicolumn{10}{|c|}{ ITU (\% total population female or male) } \\
\hline & 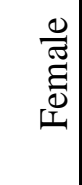 & $\frac{\stackrel{0}{\pi}}{\sum}$ & 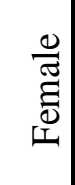 & $\frac{\stackrel{0}{\pi}}{\Sigma}$ & 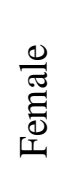 & $\frac{\frac{0}{\pi}}{\sum^{n}}$ & 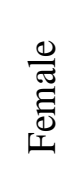 & $\frac{0}{\Sigma^{\pi}}$ & 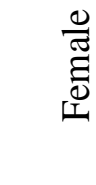 & $\frac{0}{\pi}$ \\
\hline Indonesia & - & - & 9 & 11 & 9 & 11 & 20 & 24 & 20,3 & 23,7 \\
\hline Malaysia & - & - & - & - & - & - & 69 & 73 & 69 & 73 \\
\hline Singapore & 65 & 73 & - & - & 65 & 73 & 73 & 81 & 77,3 & 81,2 \\
\hline Thailand & 24 & 23 & 27 & 26 & 29 & 29 & 39 & 40 & 38,9 & 39,7 \\
\hline
\end{tabular}




\begin{tabular}{|c|c|c|c|r|r|r|r|r|r|r|}
\hline & \multicolumn{6}{|c|}{ We Are Social (\% total Facebook active user) } \\
\hline Brunei & - & - & - & - & 44 & 56 & 44 & 56 & 44 & 56 \\
\hline Cambodia & - & - & - & - & 38 & 62 & 39 & 61 & 40 & 60 \\
\hline Lao PDR & - & - & - & - & 43 & 57 & 43 & 57 & 43 & 57 \\
\hline Philipine & - & - & - & - & 53 & 47 & 52 & 48 & 53 & 47 \\
\hline Myanmar & - & - & - & - & 36 & 64 & 36 & 64 & 36 & 64 \\
\hline Vietnam & - & - & - & - & 46 & 54 & 46 & 54 & 48 & 52 \\
\hline
\end{tabular}

*Sources : World Economic Forum Global Gender Gap Report 20132017, We Are Social Digital Report 2015-2017 ( (World Economic Forum, 2017) (World Economic Forum, 2016) (World Economic Forum, 2015) (World Economic Forum, 2014) (World Economic Forum, 2013)

(Kemp, 2017) (Kemp, 2016 Digital Yearbook, 2016) (Kemp, Digital, Social \& Mobile in APAC in 2015, 2015)

*Note : World Economic Forum Global Gender Gap Report retrieved the data from International Telecommunication Union

Before we begin explain about the statistic, it is best to understand about the differences and the validity of the sources. Only Indonesia, Malaysia, Singapore and Thailand has the data from ITU, it is because of the ASEAN countries, only Singapore, Thailand, Indonesia and Singapore consistently gather sex- disaggregated ICT statistics. One study explain this phenomena happen because we know very little about the situation of women and ICTs, particularly in developing countries, because the data (sexdisaggregated statistics and gender indicators on ICTs) in many cases are not there (Hafkin \& Huyer, 2007). Another study suggest to use Facebook in the absence of data for internet user by gender that they called Facebook Gender Gap Index. They argue that we can use Facebook data because more than half of all internet users are Facebook user. We can use it by combining online Facebook-derived indicators that come from Facebook's marketing application programming interface (API) in combination with offline, country- level development indicators that come from different data sources and include indicators for gender specific internet users from the ITU and mobile users from the GSMA, as well as general development and gender-specific 
development indicators (Fatehkia, Kashyap, \& Weber, 2018). Hence, the author use data from Facebook to other six remaining countries. The equation for Facebook Gender Gap Index is:

Based on the equation above, the results of Facebook Gender Gap Index (FGGI) as follow:

Table 1.1. Facebook Gender Gap

Index

\begin{tabular}{|c|c|c|c|}
\hline \multirow{2}{*}{ Country } & \multicolumn{3}{|c|}{ Year } \\
\cline { 2 - 4 } & 2015 & 2016 & 2017 \\
\hline Brunei & 0,6 & 0,7 & 0,7 \\
\hline Cambodia & 0,6 & 0,6 & 0,6 \\
\hline Laos & 0,7 & 0,7 & 0,7 \\
\hline Myanmar & 0,5 & 0,5 & 0,5 \\
\hline Vietnam & 0,8 & 0,8 & 1 \\
\hline Philipines & 1,08 & 1,08 & 1,08 \\
\hline
\end{tabular}

From Table 1, Indonesia's percentage of female internet user in 2014-2015 was $9 \%$ with no change and with male internet user higher percentage account for $2 \%$. In 2016 there has been a significant increase in female internet user for $20 \%$. Average female internet user is $14,575 \%$ out of 126,5 million and for average male internet user is $17,425 \%$ out of 129 million.

\section{Malaysia's percentage of} female internet user from 2016-2017 is $69 \%$ with no increase, while male internet user percentage for $73 \%$, higher 4. Hence, average female internet user is $69 \%$ out of 15 million and average male internet user is $73 \%$ out of 16,1 million.

Singapore's percentage of female internet user in 2016, saw an increase in female internet user for 8 $\%$ from $65 \%-73 \%$. In 2017, saw an increase again in female internet user for $4,3 \%$ and with male internet user higher percentage of $3,1 \%$. Hence average female internet user is $70,075 \%$ out of 2,7 million and average male internet user is $77 \%$ out of 2,7 million in 2013,2015-2017.

Thailand's percentage of female internet user in 2013-2016 saw an increasing number from $24 \%-39$ $\%$ with increase as much as $5 \%$. In 2017, saw a decreasing for female internet user for $0,1 \%$ in 38,9 . Thus, average female internet user is $31,358 \%$ out of 35 million and average male internet user is 31,54 $\%$ out of 33,2 million in 2013-2017.

From Table 1.1, Brunei saw an increasing FGGI in 2015-2016 for 0,6 to 0,7 . In 2017 , there was no increase FGGI for 0,7. Cambodia saw no increasing and decreasing FGGI in 2015-2017 for 0,6. Laos saw no increasing and decreasing FGGI in 2015-2017 for 0,7. Myanmar saw no increasing and decreasing FGGI in 2015-2017 for 0,5. Vietnam saw 
no increasing FGGI in 2015-2016 for 0,8 , however in 2017 , Vietnam a great increasing FGGI for 1 raising from 0,8-1 as much as 0,2. Philipines saw no increasing and decreasing FGGI in 2015-2017 for 1,08.

According to the Table 1 and Table 1.1, we can conclude that Philipines has the best gender equality in terms of internet user by gender, followed by Thailand with slightly below Philippine. Vietnam, Indonesia, and Singapore are countries with a good result on gender equality in terms of internet user by gender. Laos, Brunei, and Cambodia are the countries with average results on gender equality in terms of internet user by gender, in which they already making a significant progress on gender equality but they still face many obstacles in regards to gender equality in internet user by gender. Myanmar is the worst country for gender equality in terms of internet user by gender.

Second data is service sector employment by gender. We can explain the relations between digital economy and service sector by simply looking into its definitions. The tertiary sector or service sector is the third of the three economic sectors of the three- sector theory. Services sectors are a diverse group of economic activities that include high technology, knowledgeintensive sub-sectors, as well as labour-intensive, low skill areas, but technological advances are, however, narrowing the differences between services and other economic activities (Muyed, 2008).

Table 2. the percentage of service sector employment by gender

\begin{tabular}{|c|c|c|c|c|c|c|c|c|c|c|}
\hline \multirow[b]{3}{*}{ Country } & \multicolumn{10}{|c|}{ Year } \\
\hline & \multicolumn{2}{|c|}{2013} & \multicolumn{2}{|c|}{2014} & \multicolumn{2}{|c|}{2015} & \multicolumn{2}{|c|}{2016} & \multicolumn{2}{|c|}{2017} \\
\hline & 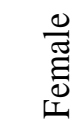 & $\frac{0}{\sum^{\pi}}$ & 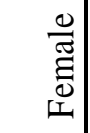 & $\frac{\frac{0}{\sigma}}{\Sigma}$ & 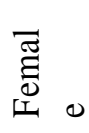 & $\frac{0}{\pi}$ & 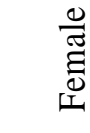 & $\frac{0}{\pi}$ & $\begin{array}{c}\frac{0}{\tilde{J}} \\
\stackrel{\Xi}{0} \\
\text { I. }\end{array}$ & $\sum_{\Sigma}^{\frac{0}{\pi}}$ \\
\hline Brunei & 88,1 & 73,5 & 88,6 & 75,2 & 88,5 & 75,3 & 89,3 & 76 & 89,4 & 76,3 \\
\hline Cambodia & 42,6 & 42 & 44,1 & 42,8 & 45,4 & 43,4 & 46,9 & 44,1 & 47,9 & 44,7 \\
\hline Indonesia & 50,4 & 40,3 & 51,2 & 40,2 & 51,7 & 40,9 & 54 & 41,7 & 54,8 & 42,3 \\
\hline Lao PDR & 25,1 & 25,3 & 26,4 & 26,2 & 27,7 & 27,1 & 29,1 & 27,9 & 29,7 & 28,3 \\
\hline Malaysia & 71,7 & 51 & 71,9 & 52,4 & 72,9 & 52,2 & 73,2 & 53,8 & 73,6 & 54,2 \\
\hline
\end{tabular}




\begin{tabular}{|c|c|c|c|c|c|c|c|c|c|c|}
\hline \multirow[b]{3}{*}{ Country } & \multicolumn{10}{|c|}{ Year } \\
\hline & \multicolumn{2}{|c|}{2013} & \multicolumn{2}{|c|}{2014} & \multicolumn{2}{|c|}{2015} & \multicolumn{2}{|c|}{2016} & \multicolumn{2}{|c|}{2017} \\
\hline & $\begin{array}{l}\frac{0}{\tilde{J}} \\
\text { है } \\
\text { [I }\end{array}$ & $\frac{\frac{0}{\pi}}{\Sigma}$ & $\begin{array}{l}\frac{0}{\tilde{J}} \\
\text { है } \\
\text { [I }\end{array}$ & $\frac{\frac{0}{\pi}}{\Sigma}$ & 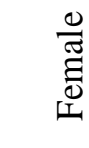 & $\frac{0}{\Sigma \pi}$ & 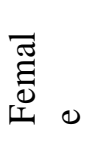 & $\frac{\frac{0}{\pi}}{\Sigma}$ & $\begin{array}{c}\frac{0}{\tilde{J}} \\
\stackrel{\vec{J}}{0} \\
\underline{\underline{T}}\end{array}$ & $\frac{\frac{0}{\pi}}{\Sigma}$ \\
\hline Myanmar & 31,5 & 26,3 & 33,3 & 27,4 & 35,2 & 28,9 & 36,3 & 29,7 & 37,6 & 30,7 \\
\hline Philipine & 69,6 & 42,9 & 69,6 & 43,1 & 71 & 43,9 & 72,6 & 44,3 & 73,6 & 44,9 \\
\hline Singapore & 85,1 & 76,2 & 87,4 & 78,7 & 87,6 & 78,7 & 88,3 & 79,8 & 88,2 & 79,8 \\
\hline Thailand & 44,4 & 34,9 & 48,2 & 38,7 & 49,4 & 39,5 & 49,4 & 39,4 & 50,3 & 39,9 \\
\hline Vietnam & 34,3 & 29,9 & 34,4 & 39,4 & 35,1 & 30,7 & 35,7 & 31,2 & 36,6 & 31,7 \\
\hline
\end{tabular}

*Source: World Bank Data (World Bank, 2017) (World Bank, 2017)

*Note: Female: percentage of total female employment, Male: percentage of male employment

From Table 2, Brunei saw an increase each year in 2013-2017 for the percentage of service sector employment by the female from 88,1 $\%$ to $89,4 \%$ with average increasing for $88,78 \%$. For its male counterpart, it was also increasing each year in 2013-2017 from 73,5 \% to 76,3 with average increasing for $75,26 \%$. Thus, the average difference between female and male is $13,52 \%$.

Cambodia saw an increase each year in 2013-2017 for the percentage of service sector employment by female from $42,6 \%$ to $47,9 \%$ with average increasing for $45,38 \%$. For its male counterpart, it was also increasing each year in 2013-2017 from $42 \%$ to $44,7 \%$ with average increasing for $43,4 \%$. Thus the average difference between female and male is $1,98 \%$.

Indonesia saw an increase each year in 2013-2017 for the percentage of service sector employment by the female from $50,4 \%$ to $54,8 \%$ with average increasing for $52,42 \%$. \% For its male counterpart, it was also increasing each year in 2013- 2017 from $40 \%$ to $42,3 \%$, with the only exception in 2013-2014 decreasing for $0,1 \%$, and average increasing for $41,15 \%$. Thus, the average difference between female and male is $11,27 \%$.

Laos saw an increase each year in 2013 -2017 for the percentage of service sector employment by the female from $25,1 \%$ to $29,7 \%$ with average increasing for $27,6 \%$. For its male counterpart, it was also increasing each year in 2013-2017 
from $25,3 \%$ to $28,3 \%$ with average increasing for $26,96 \%$. Thus, the average difference between female and male is $1,34 \%$.

Malaysia saw an increase each year in 2013-2017 for the percentage of service sector employment by the female from $71,7 \%$ to $73,6 \%$ with average increasing for $72,66 \%$. For its male counterpart, it was also increasing each year in 2013-2017 from $51 \%$ to $54,3 \%$ with average increasing for $52,72 \%$. Thus, the average difference between female and male is $19,94 \%$.

Myanmar saw an increase each year in 2013-2017 for the percentage of service sector employment by the female from $31,5 \%$ to $37,6 \%$ with average increasing for $34,6 \%$. For its male counterpart, it was also increasing each year in 2013-2017 from $26,3 \%$ to $30,7 \%$ with average increasing for $28,6 \%$. Thus, the average difference between female and male is $6 \%$.

Philippine saw an increase each year in 2013-2017 for the percentage of service sector employment by the female from $69,6 \%$ to $73,6 \%$ with average increasing for $71,28 \%$. For its male counterpart, it was also increasing each year in 2013-2017 from $42,9 \%$ to $44,9 \%$ with average increasing for $43,82 \%$. Thus, the average difference between female and male is $27,46 \%$.

Singapore saw an increase each year in 2013-2017 for the percentage of service sector employment by the female from $85,1 \%$ to $88,2 \%$ with average increasing for $87,32 \%$. For its male counterpart, it was also increasing each year in 2013-2017 from $76,2 \%$ to $79,8 \%$ with average increasing for $78,64 \%$. Thus, the average difference between female and male is $8,68 \%$.

Thailand saw an increase each year in 2013-2017 for the percentage of service sector employment by the female from $44,4 \%$ to $50,3 \%$ with average increasing for $48,34 \%$. For its male counterpart, it was also increasing each year in 2013-2017 from $34,9 \%$ to $39,9 \%$ with average increasing for $38,48 \%$. Thus, the average difference between female and male is $9,86 \%$.

Vietnam saw an increase each year in 2013-2017 for the percentage of service sector employment by the female from $34,3 \%$ to $36,6 \%$ with average increasing for 35,22 $\%$. For its male counterpart, it was also increasing each in 2013-2014 from $29,9 \%$ to 39,4 , but then saw a decline in 2015 decreasing for 8,7\% and after that, saw an increase again in 2015-2017 from $30,7 \%$ to $31,7 \%$ 
with average increasing for $32,68 \%$. Thus, the average difference between female and male is 2,54 \%.

From Table 2 we can conclude that the smallest gender gap between women and men in service sector employment percentage above $20 \%$ is only Philippine. The percentage between $11 \%-20 \%$ are Malaysia, Brunei, and Indonesia. The percentage of $5 \quad \% \quad-10 \%$ are Thailand, Singapore, and Myanmar. Last, the percentage between $1 \%-5$ $\%$ are Vietnam, Cambodia, and Laos.

However, if we only compare the average difference between the female and male gap in service sector employment, it will not be sufficient enough to best explain about women's participation in the digital economy, specifically women's participation in employment. Thus, it will be useful if we compare it also with average percentage of female unemployment and again, the percentage of female employment in the service sector in 2013-2017 (World Bank, 2018) . Philipines, although has one of the highest average female unemployment rate for $3,32 \%$, but consider its highest rate on average differences between women and men in service sector and one of the highest rate on female employment in service sector only behind Brunei and Singapore, we can conclude that Philipines has the largest women's participation in employment. Malaysia, Thailand, and Singapore has one of the lowest average female unemployment rates for $3,56 \%, 0,76 \%$, and $2,03 \%$, and has one of the highest rates on average differences between women and men in service sector and female employment in service sector, it is also undeniable for both countries as one of the countries with one of the highest women's participation in employment. Indonesia and Vietnam, although Indonesia has the highest average female unemployment rate on 4,06 only behind Brunei, but considering Indonesia high rate on percentage of female employment in service sector and average differences between women and men in service sector, and considering Vietnam high rate on percentage of female employment in service sector and one of the lowest average female unemployment rate on $1,94 \%$, we can conclude that both countries have a significant large women's participation in employment. Brunei has the highest average female service sector employment and one of the highest average difference between women and men service sector employment, 
but it is also the highest country with average female unemployment rate with $7,8 \%$, hence, Brunei still faces a lot of problem regarding women's employment. Although Cambodia, Myanmar, and Laos has the lowest female unemployment with rate of $0,22 \%, 0,9 \%$, and 0,16 $\%$ respectively, but, they have the lowest percentage of female employment in service sector and average differences between women and men in service sector, it is a consideration that those countries have the smallest women's participation in employment.

Third data is ICT Development Index. ICT Development Index or IDI is an index published by the United Nations International Telecommunication Union which brings together indicators concerned with ICT access, use, and skills into a single comparative measure of development towards the information society. The value can be measured by scale $1-10$ with 1 is the least value and 10 is the best value

(International Telecommunication Union, 2018).

One study show the correlation between ICT, rural and urban areas.
Theoretical considerations as to how the ICT should develop in order to create benefits for everyone are in great contrast with rural reality. Developments so far indicate that telecommunication companies will not provide every rural household or business with a high-speed Internet connection comparable to those in urban areas. Rural areas are served last, if they are served at all. The speed and reliability of connections in rural areas demonstrate this. Compared to urban areas, the profit opportunity in rural areas is lower because of the high costs of covering greater distances. Companies are only willing to deploy a network if households and businesses pay a higher price to make up for these higher deployments costs. Insights from the connectivity debate show that, under the current conditions, we can expect that the urban-rural divide will persist or even grow, as new, faster technologies come on-stream, perpetuating the rural penalty. There is a growing consensus that poor rural telecommunication infrastructure hinders rural development (Salemink, Bosworth, \& Strijker, 2017) 
Table 3. ICT Development Index

\begin{tabular}{|c|c|c|c|c|c|c|c|c|}
\hline \multirow{3}{*}{ Country } & \multicolumn{7}{|c|}{ Year } \\
\cline { 2 - 10 } & \multicolumn{2}{|c|}{2013} & \multicolumn{2}{|c|}{2015} & \multicolumn{2}{|c|}{2016} & \multicolumn{2}{|c|}{2017} \\
\cline { 2 - 10 } & Rank & Value & Rank & Value & Rank & Value & Rank & Value \\
\hline Brunei & 66 & 5,43 & 77 & 5,33 & 74 & 5.75 & 53 & 6,75 \\
\hline Cambodia & 127 & 2,61 & 125 & 3,12 & 127 & 2,78 & 128 & 3,28 \\
\hline Indonesia & 106 & 3,83 & 107 & 4,28 & 106 & 3,97 & 101 & 4,67 \\
\hline Lao PDR & 134 & 2,61 & 144 & 2,45 & 144 & 2,21 & 139 & 2,91 \\
\hline Malaysia & 71 & 5,20 & 61 & 6,22 & 66 & 5,64 & 63 & 6,38 \\
\hline Myanmar & 150 & 1,82 & 140 & 2,54 & 153 & 1,95 & 135 & 3,80 \\
\hline Philipine & 103 & 4,02 & 107 & 4,28 & 106 & 3,97 & 101 & 4,67 \\
\hline Singapore & 16 & 7,90 & 20 & 7,95 & 19 & 7,88 & 18 & 8,05 \\
\hline Thailand & 81 & 4,76 & 82 & 5,18 & 79 & 5,05 & 78 & 5,67 \\
\hline Vietnam & 101 & 4,09 & 105 & 4,29 & 104 & 4,02 & 108 & 4,43 \\
\hline
\end{tabular}

*Source: International Telecommunication Union (International

Telecommunication Union, 2013) (International Telecommunication

Union, 2015) (International Telecommunication Union, 2016)

(International Telecommunication Union, 2017)

From Table 3, we can conclude that countries in ASEAN that has better average ICT Development Index in 2013,20152017 are Singapore with value 7,945, Malaysia with value 5,86, Brunei with value 5,85, Thailand with value 5,165 , Vietnam with value 4,275 , Philipines with value 4,235 , Indonesia with value 4,1 , Laos with value 2,545, Myanmar with value 2,5275, and Cambodia with value 2,358 .

If we compare the results between Table 1, Table 1.1 and Table 2 with Table 3 , as it is already mentioned above, there is a strong correlation between ICT in general and rural areas. Philippine so far has the largest women's participation in digital economy because of its average high percentage rate in internet user with FGGI 1,08 and highest percentage rate on female service sector employment, even though that its average IDI value is below 5 and it is behind Vietnam. Malaysia is the next country in ASEAN that has the largest women's participation in digital economy considering its high average female internet user with 69 $\%$, one of the 
highest average rates on female service sector employment only after Philipines and with highest average IDI only after Singapore with value 5,86. Singapore is coming next as a country with the largest women's participation in the digital economy, considering its high average female internet user with $70,075 \%$, one of the highest average rates on service sector employment rate only after the Philippines, Malaysia, and Thailand, and highest average IDI with value 7,945 . Thailand is then coming next as the largest country on women's participation in the digital economy, considering its high average female internet user with $31,358 \%$, high average female service sector employment only after Philipines and Malaysia, and high IDI with value 5,165. Vietnam comes next as a country with the largest women's participation in the digital economy, considering its high average female internet user with FGGI 0,8-1, high average female service sector employment only after Philipines, Malaysia, Thailand, Singapore and Indonesia, and high average IDI with value 4,275. Indonesia comes next as a country with the largest women's participation in the digital economy, considering its average female internet user with $14,575 \%$, high average female service sector employment only after Philipines, Malaysia, Thailand and Singapore, and average IDI with value 4,1 . Brunei comes next as a country with the largest women's participation in the digital economy, considering its average female internet user with FGGI 0,6-0,7, highest average female service sector employment but with the highest female unemployment rate, and average IDI with value 5,85 . Laos is the next country with the largest women's population in the digital economy, considering its average female internet user with FGGI 0,7, its average female service sector employment after Cambodia and Myanmar, and its average IDI with value 2,545. Cambodia is then the next country with the largest women's participation in the digital economy, considering its average female internet user with FGGI 0,6, average female service sector employment before Myanmar and Cambodia, and average IDI with value 2,358. Myanmar is a country with the smallest women's participation in the digital economy, considering its lowest average female internet user with FGGI 0,5, average female service sector employment only before Laos, and average IDI with value 2,575.

Singapore and Malaysia are the countries with the highest 
urbanization in ASEAN, and yet they have high results. Philipines, Thailand, and Indonesia are the countries with the middle level of urbanization, but they have high results too. Laos, Cambodia, and Myanmar are the countries with the least urbanization and that is a parallel line with their results. Unique cases are Brunei and Vietnam. Brunei is the country with the second highest urbanization, but it has a low result because it mainly comes from its highest percentage of female unemployment rate among ASEAN countries. Vietnam, on the contrary, is one of the lowest urbanization in ASEAN, and it has the high result because it mainly comes from its government reformation policy. Thus, rural area has better women's participation in the digital economy and urban area have worst women's participation in digital economy in ASEAN, except for Brunei and Vietnam.

\section{WOMEN'S PARTICIPATION}

No doubt that more and more women in ASEAN countries could join the labor force by choice, responding to rising economic conditions, educational attainments and the growing opportunities to work and to progress in their careers. At the sector level this pattern certainly reflects the growing demand for qualified labour from the service sector. If wee look at the percentage of female unemployment rate, low income countries have the least percentage, but it is mainly because majority of women work in the informal sector and their labour markets outcomes are relatively poor. In the contrary, higher income countries have bigger percentage of female unemployment rate, but majority of women works in formal sector and they have better outcomes of labour markets.

E-commerce has become the biggest trend in Digital Economy whereas all of the transactions is through internet with the biggest market are Singapore, Malaysia, Thailand, Philipines and Vietnam. (ASEAN UP, 2018). Women is the biggest contributor in terms of ecommerce purchase, in which they contribute $80 \%$ if all household purchases and spend $40 \%$ more time on online retailer. They purchased online in fashion, household, groeceries, financial services and autumotive (Febriana, 2017).

An estimated 61.3 million women entrepreneurs own and operate businesses and around 24 million women own micro, small and medium-size enterprises 
(MSMEs) in the region, and the number of women-owned enterprises is growing faster than those that are male-owned. Women are increasingly choosing to be self-employed, starting their own companies and entering emerging sectors like ecommerce (United Nations Economic and Social Commision for Asia and The Pacific, 2017)

At least five of the ASEAN countries have adopted national digital economy or ICT strategies (Brunei, Malaysia, the Philippines, Thailand, and Singapore). Developing initiatives to ensure that women are not left behind is essential, including the participation of women-owned enterprises. In ASEAN, there are some of programs and initiatives to introduce women, including women entrepreneurs, to ICTs, that are initiated and carried out by the government, ICT providers, community organizations, and women entrepreneurs' associations and networks (Kogiso, et al., 2017).

\section{OBSTACLES}

The development of women's participation in the digital economy in ASEAN is still with obstacles eventhough there have been a remarkable increasing in women's participation. The obstacles as explain below (Kogiso, et al., Loc. Cit.) (UN Women Asia-Pacific, 2016)

1. The tables do not necessarily translate into optimal economic outcomes for women eventhough that the results is positive. For example, in the low income countries, women's labour force participation tends to be driven by economic necessity rather than opportunity. Many women across the region are relegated to work in low value-added and informal jobs, whilst they continue to receive significantly lower wages than their male counterparts.

2. Although governments, companies, and organizations in some of the ASEAN countries have launched programmes with the purpose to train women entrepreuners in ICT, women are still lagging behind in terms of the income.

3. Access to fnancial services is low and uneven across ASEAN, in particular for women. Several countries have lending programs aimed at women, but these are often not made the most of. This limits their ability to borrow, invest or save money, 
in the household or in business. Especially womenowned SMEs is the most disadvantage from this.

4. Despite the increasing visibility of the issue, our ability to measure gender gaps in access to the internet and mobile phones is significantly limited due to data gaps. The lack of sex-disaggregated data on internet and mobile phone access as "one of the key barriers" for measuring progress in development goals that call for gender equality in access to the internet.

5. Women who start businesses usually know fewer other entrepreneurs and often lack the social connections that can off fer further opportunities, information, and contacts Women entrepreneurs have highlighted the lack of access to relevant information, connections, capital and labour.

6. There's still biases in acces to ICT that stem from cultural belief. The challenges girls face in developing an interest in ICT stem from gender biases that stereotype technology as a male domain. For girls and women, barriers to acquiring ICT skills include limited time to pursue ICT skill adoption, restricted mobility, a lack of physical and online safety, limited willingness of families to invest in ICT training for girls compared to boys, and a lack of gender-sensitive training content and delivery. Gender discrimination in hiring and promotion practices at the workplace is a barrier to entering the workforce and renders many existing ICT jobs unattractive to women.

7. Education has been a main barrier to women's empowerment from a long time ago. Although that the average number years of school attendance has increased across the board, but a gap persists between girls and boys in which giils still spend fewer years in school. But, the improvement in terms of years of educaion does not translating to equal opportunitie for women in the labour force, even in more prosperous countries.

8. Customary laws and traditional practices limit women's access to credit, asset ownership and other economic opportunities, even though all ASEAN Member States provide for 
constitutional equality

between men and women.

9. Female labour force participation rate is persistently lower than men across all ASEAN Member States. While the gap may have shrunk in some countries, it has widened in others. Woman consistently earn less than men in the same sectors, with the pay gap reaching 25 per cent in some countries. Paying women less, and keeping them in lower-end roles, deprives them of the income, and those sectors of their potential contribution.

10. ASEAN woman does not enjoy state-sponsored flexible work arrangements or help in balancing professional and domestic obligations, leading many to work less or leave employment early. Women's unpaid work in child-rearing and household tasks remains unaccounted for in national income but contributes considerable value. In some countries, women's help with family businesses is more often unpaid than that of their male relatives. Married women spend an estimated 3.5 hours per day more than married men on unpaid care work.

\section{CONCLUSION}

The booming of the digital economy over the past five years had an enormous impact on increasing women's economic condition. Digital economy brings a great opportunity for women to increase their income and have a better employment. We have seen for the past five years that women's participation in the digital economy in ASEAN had increased significantly, even though that the increasing level are various in every member States. However, women still face some obstacles in order to fully participates in the digital economy. These obstacles hinder the equal opportunities for women to have a better economic condition comparing to men. It is therefore important for us to identifies this obstacle, to minimize it and even to remove it. All of this is one of many ways to help women have equal opportunities comparing to men in the economic sector.

\section{REFERENCES}

ASEAN UP. (2018, February 14). Overview of $e$ - commerce in Southeast Asia [market analysis]. Retrieved from ASEAN UP Web Site: https:// aseanup.com/overview-of-ecommerce-in-southeast-asia/ accessed in April 122018 
ASEAN UP. (2018, January 18). Southeast Asia Digital Economy 2017 (report). Retrieved from ASEAN UP Web Site: aseanup. com/southeast-asia -digitaleconomy-2017/amp/ accessed in April 122018

Box, S., \& Lopez-Gonzalez, J. (2017). The Future of Technology: Opportunities for ASEAN in the Digital Economy. In S. I. Affairs, \& A. o. Nations, Global Megatrends: Implications for the ASEAN Economic Community (pp. 37-60). Jakarta: ASEAN Secretariat.

Bukht, R., \& Heeks, R. (2017). Defining, Conceptualising and Measuring the Digital Economy. Development Informatics Working Paper Series; Paper No. 68.

Economic Commission for Latin America and the Caribbean. (2013). Women in the digital economy; Breaking Through the Equality Treshold. Santiago: United Nations. Fatehkia, M., Kashyap, R., \& Weber, I. (2018). Using Facebook ad data to track the global digital gender gap. World Development 107, 189-209.

Febriana. (2017, April 7). Wome Are Lading The Future of
E-Commerce In South East Asia. Retrieved from Ground Report Web Site: https://www. groundreport.com/women-areleading-the-future-of-ecommerce- in-south-east-asia/ accessed in April 122018

Hafkin, N. J., \& Huyer, S. (2007). Women and gender in ICT statistics and indicators for development. Information Technologies \& International Development, Volume 4, Number 2, 25-41.

International Telecommunication Union. (2013). Measuring The Information Society 2013. Geneva: International

Telecommunication Union.

International Telecommunication Union. (2015). Measuring The Information Society Report 2015. Geneva: International Telecommunication Union.

International Telecommunication Union. (2016). Measuring The Information Society Report 2016. Geneva: International Telecommunication Union. International Telecommunication Union. (2017). Measuring The Information Society Report 2017. Geneva: International Telecommunication Union. 
International Telecommunication Union. (2018). The ICT Development Index (IDI): conceptual framework and methodology. Retrieved

f r o m I n t e r n a t i o n a 1 Telecommunication Union Web Site: https://www.itu. int/en/ITU - D/Statistics/ Pages/publications/mis2017/ methodology.aspx accessed in April 122018

Kemp, S. (2015). Digital, Social \& Mobile in APAC in 2015.

London: We Are Social.

Kemp, S. (2016). 2016 Digital

Yearbook. London: We Are Social.

Kemp, S. (2016). 2016 Digital

Yearbook. London: We Are Social.

Kemp, S. (2017). Digital in 2017

Global Overview. London: We Are Social, Hootsuite.

Kogiso, M., Yu, L., Masuda, R., Gupta, G., Naoko, K., Oberoi, J. V., . . . Reddhy, S. (2017). Advancing Women's Empowerment: ICT Skills For Girls And Women. Tokyo: The Sasakawa Peace Foundation, Dalberg Global Development Advisors.

Lechman, E., \& Okonowicz, A. (2013). Are Woman Important for Economic Development?: An Evidence on Women's Participation in Labor Market and Their Contribution to Economic Growth in 83 Countries. GUT FME Working Papers Series A.

Menon, Naven, Ghee Chua, S., Dobberstein, N., Choi, J., Ranganathan, S., . . . Monga, N. (2016). The ASEAN's Digital Revolution. Singapore: A.T. Kearney.

Muyed, S. (2008). The Tertiary Sector is Going To Dominate The World. Munich Personal RePEc Archive Paper No. 14681.

Nelson, J. A. (1995). Feminism and Economics. Journal of Economic Perspectives Volume 9 Number 2, 131-148. Salemink, K., Bosworth, G., \& Strijker, D. (2017). Rural development in the digital age: A systematic literature review on unequal ICT availability, adoption, and use in rural areas. Journal of Rural Studies, Volume 54, 360-371.

Tapscott, D. (1996). The Digital Economy: Promise and Peril in the Age of Networked Intelligence. New York: McGraw-Hill.

UN Women Asia -Pacific. (2016). Infographics - ASEAN women 
are a potential boost to the region's labour force and economy. Bangkok: UN Women Regional Office for Asia and the Pacific.

United Nations Economic and Social Commision for Asia and The Pacific. (2017). Fostering Women's Entrepreneurship in ASEAN: Transforming Prospects, Transforming Societies. Bangkok: United Nations Publication.

World Bank. (2016). Population, female (\% of total). Retrieved from The World Bank Data Web Site: https://data. worldbank.org/indicator SP.POP .TOTL .FE.ZS ?end $=2016 \&$ locations $=$ ID-SGBN-TH-PH-MM-KH-LAVN\&start $=2016$ accessed in April 182018

World Bank. (2017). Employment in services, female (\% of female employment) (modeled ILO estimate). Retrieved from The World Bank Data Web Site: https://data. worldbank. org/i ndicator/SL.S RV.EMPL .FE .ZS?end $=2017 \&$ locations $=$ IDSG-BN-TH-MM -MY-LAKH-PH\&start=2013 accessed in April 182018

World Bank. (2017). Employment in services, male (\% of male employment) (modeled ILO estimate). Retrieved from The World Bank Data Web Site: https://data.worldbank. org/i ndicator/SL.SRV .EMPL.MA .ZS?end=2017\&locations=IDSG-BN-TH-MM -MY-LAKH-PH\&start=2013 accessed in April 182018

World Bank. (2018). Unemployment, female (\% of female labor force) (modeled ILO estimate). Retrieved from The World Bank Data: https://data.worldbank. org/indicator/SL.UEM.TOTL.

FE.ZS?locations=ID-SG-BN-TH - MM - MY- L A- KH - PH accessed in April 182018

World Economic Forum. (2013). The Global Gender Gap Report 2013. Geneva: World Economic Forum.

World Economic Forum. (2014).

The Global Gender Gap Report 2014. Geneva: World Economic Forum.

World Economic Forum. (2015).

The Global Gender Gap Report 2015. Geneva: World Economic Forum.

World Economic Forum. (2016). The Global Gender Gap Report 2016. Geneva: World Economic Forum. 
World Economic Forum. (2017).

The Global Gender Gap Report 2017. Geneva: World Economic Forum.

Xin, M. (1996). The Economic

Position of Women in Asia - Asian-Pacific Economic

Literature, 23-41. 